\title{
Investigation of fimH Single Nucleotide Polymorphisms (C640T and T591A) in Uropathogenic E. coli Isolated from Patients with Urinary Tract Infections
}

\author{
Razieh Molaie ${ }^{1}$, Fariba Dehghanian ${ }^{2}$, Zohreh Hojati ${ }^{2}$, Abolfazl Gholipour ${ }^{3 *}$ \\ ${ }^{1}$ Cellular and Molecular Research Center, Shahrekord University of Medical Sciences, Shahrekord, Iran. \\ ${ }^{2}$ Division of Genetics, Biology Department, Faculty of Sciences, University of Isfahan, Isfahan, Iran. \\ 3 Department of Microbiology and Immunology, Cellular and Molecular Research Center, Faculty of Medicine, Shahrekord University of \\ Medical Sciences, Shahrekord, Iran.
}

\author{
Received: 21 Feb 2016 \\ Revised : 18 Mar 2016 \\ Accepted: 30 Mar 2016 \\ Corresponding Author: \\ Abolfazl Gholipour, \\ Department of Microbiology and \\ Immunology, Cellular and Molecular \\ Research Center, Faculty of Medicine, \\ Shahrekord University of Medical \\ Sciences, Shahrekord, IR Iran. \\ Phone: +98-9137046656 \\ E-mail: \\ gholipour_abolfazl@yahoo.com
}

\begin{abstract}
Background: Urinary tract infections (UTIs) are one of the most frequent health problems and uropathogenic Escherichia coli is the major pathogen resulting in UTIs. Sever forms of UTIs are caused by expression of a large range of virulence factors. In this study, we evaluated the allelic frequency fim $H$ gene, in uropathogenic strains of Escherichia coli (UPECs) isolated from patients with UTIs. This study also aimed at determining the roles of C640T and T591A SNPs of the fimH gene in the ability of UPEC to cause UTIs.

Materials and Methods: A total of 140 UPEC strains isolated from patients with UTIs were screened by PCR-RFLP to determine the prevalence of the fimH gene C640T and T591A SNPs in UPEC strains isolated from patients attending educational hospitals in Shahrekord. The genotyping of C640T and T591A SNPs was performed using Bme1390I and BseNI restriction enzymes, respectively through PCR-RFLP method.

Results: There were no significant association between C640T and T591A SNPs of $f i m H$ gene and the ability of UPEC fimH variants to cause UTIs in the studied E.coli isolates.

Conclusion: FimH is one of the major virulence factors among UPECs which is confirmed in most E.coli isolates. Further studies are required to determine the association between different fimH gene SNPs of isolated UPECs from patients with UTIs and the ability of UPEC fimH variants to cause UTIs.
\end{abstract}

Keywords: UTIs; fimH; C640T and T591A SNPs; PCR-RFLP

Please cite this article as: Molaie R, Dehghanian F, Hojati Z, Gholipour A. Investigation of fimH Single Nucleotide Polymorphisms (C640T and T591A) in Uropathogenic E. coli Isolated from Patients with Urinary Tract Infections. Res Mol Med. 2016; 4 (2): 9-14

\section{Introduction}

Urinary tract infection (UTI) is one of the most widespread infections in humans which causes severe morbidity and significant expenditures (1). UTIs affect different parts of the urinary tract and are classified into various disease groups based on infection sites. UTIs are categorized into cystitis (the bladder), pyelonephritis (the kidney) and bacteriuria (the urine) (2-4). Uropathogenic Escherichia coli (UPEC) strains are considered as a primary pathogen in about $80 \%$ of patients with UTIs $(5,6)$. Successful establishment of infection by UPECs needs different cascade of events including adhesion to host cells colonization of tissues and in certain cases, cellular invasion. These events include different cellular and molecular pathways which depend on the presence of multiple virulence factors (7). In fact, various range of virulence factors including siderophore receptors encoding genes, iron intake system, type 1 fimbriae encoding genes and hemolysin encoding gene amplify the pathogenicity of UPEC strains and the severity of UTIs $(8,9)$.

Among all cellular pathways relating to UPECs infection, adherence is an essential step. Adherence of bacteria to the surface of the host cell is a preliminary stage in colonization and central step relating to infection (10). This step is mediated by 
structures called adhesions which are cell-surface components or appendages of bacteria that make possible adherence to other cells or surfaces. Type 1 fimbriae adhesion is the best described bacterial adhesions which are very important in the mechanism of UPECs adhesion to the uroepithelium. Type 1 fimbriae involves a number of subunits, the most significant of which is an adhesion protein identified as FimH $(11,12)$. FimH, which is located at the tip of type 1 fimbriae plays a major role in the pathogenesis mechanism of UPECs at urinary tract. It mediates binding to $\alpha$-D-mannosylated glycoproteins, which are located on epithelial cells of the urinary tract.

Recently, a variety of single nucleotide polymorphisms (SNPs) have been identified in bacterial pathogens which belong to pathoadaptive mutations (13). These mutations defined as genetic alterations in regulatory or structural genes that lead to discriminative benefits during infection. Different Phenotypic variants of FimH subunit provide important advantages to the bacteria in the colonization of the urinary tract and its pathogenicity $(14,15)$. In this study, we attempt to investigate the association between C640T and T591A SNPs of fimH gene and its effect on the severity of pathogenicity of UPECs to cause UTIs. In addition, possible interactions between the polymorphisms, age and gender status were also analyzed.

\section{Materials and Methods \\ Bacterial isolates}

A total of $140 \mathrm{E}$. coli isolates was collected from the urine samples of patients with UTIs during inpatient and outpatient treatment in Educational Hospitals of Shahrekord, Iran, during April to July 2012. Patients who stayed in a ward for clinical treatment were considered as inpatients. Outpatients were defined as patients who were not hospitalized for 24 hours or more, but who visited a hospital or clinic for diagnosis and treatment. All the isolates originated from inpatients and outpatients with significant $E$. coli bacteriuria (defined as $\geq 10^{5} \mathrm{CFU} \mathrm{ml}^{-1}$ in cleanvoided urine). The microbiological characteristics of all bacterial isolates were identified using standard biochemical identification methods $(16,17)$. E. coli reference strains K-12 (Pasteur Institute, Iran) was also studied as a positive control for PCR reaction.

\section{DNA isolation}

A sweep of each sample growth on a nutrient agar was boiled in $500 \mu \mathrm{l}$ of distilled water for 10 minutes in order to extract DNA. After thermal lysis, centrifugation was done at $12000 \mathrm{rpm}$ for 7 minutes to pellet the cell debris. The supernatant was transferred to a new vial, kept at $20^{\circ} \mathrm{C}$ and used as the template for PCR amplification.

\section{Genotyping analyses}

The genotyping of C640T and T591A SNPs was carried out using PCR-RFLP method. The primers for SNPs were designed using the primer design software Oligo 7 and were listed as follows:

Forward primer (C640T): 5' GTGCCAATTCC TCTTACCGTT 3'

Reverse primer (C640T): 5' TGG AAT AAT CGT ACC GTT GCG 3'

Forward primer (T591A): 5' CCG TTA CTC TGC CGG ACT ACA C 3'

Reverse primer (T591A): 5' CCC AGG TTT TGG CTT TTC GCA CAA T 3'

The Touchdown PCR reaction for C640T genotyping was performed in $25 \mu \mathrm{l}$ reaction mixture containing $0.5 \mu \mathrm{l}$ of each forward and reverse primers $(10 \mathrm{pM})$, $2.5 \mu \mathrm{l}$ of $10 \times$ solution buffer $(20 \mathrm{mM}$ Tris- $\mathrm{HCl} \mathrm{pH}$ 8.6, $50 \mathrm{mM} \mathrm{KCl}$, Cinnagen Inc, Iran), $1 \mu \mathrm{l}$ of four mixed dNTPs (10 mM, Cinnagen Inc, Iran), $1 \mu 1$ of Mgcl2 (50 mM, Cinnagen Inc, Iran), $0.1 \mu \mathrm{l}$ of $5 \mathrm{u} / \mu \mathrm{l}$ Taq DNA polymerase (Cinnagene, Co., Iran), $2 \mu 1$ $(100 \mathrm{ng} / \mu \mathrm{l})$ of template DNA.

The Touchdown PCR program for C640T genotyping was as follows: initial denaturation for $3 \mathrm{~min}$ at $96^{\circ} \mathrm{C}$ followed by 10 cycles of $30 \mathrm{sec}$ at $96^{\circ} \mathrm{C}, 30 \mathrm{sec}$ at 64 ${ }^{\circ} \mathrm{C}, 72{ }^{\circ} \mathrm{C}$ for $30 \mathrm{sec} ; 24$ cycles of $30 \mathrm{sec}$ at $96^{\circ} \mathrm{C}, 30$ sec at $54{ }^{\circ} \mathrm{C}, 72{ }^{\circ} \mathrm{C}$ for $30 \mathrm{sec}$ and a final extension step of $7 \mathrm{~min}$ at $72{ }^{\circ} \mathrm{C}$. The Touchdown PCR reaction mixture for genotyping of T591A SNP was as follows: $0.5 \mu \mathrm{l}$ of each forward and reverse primers, $2.5 \mu \mathrm{l}$ of $10 \times$ solution buffer, $1 \mu \mathrm{l}$ of four mixed dNTPs (10 mM, Cinnagen Inc, Iran), $1.5 \mu \mathrm{l}$ of $\mathrm{Mgcl} 2$, $0.1 \mu \mathrm{l}$ of Taq DNA polymerase and $2 \mu \mathrm{l}$ of template DNA. The Touch-down PCR program for T591A genotyping was carried out with the following temperature profile: an initial step at $96{ }^{\circ} \mathrm{C}$ for $3 \mathrm{~min}$ followed by 7 cycles of $30 \mathrm{sec}$ at $96^{\circ} \mathrm{C}, 30 \mathrm{sec}$ at 69 ${ }^{\circ} \mathrm{C}, 72{ }^{\circ} \mathrm{C}$ for $20 \mathrm{sec} ; 30$ cycles of $30 \mathrm{sec}$ at $96{ }^{\circ} \mathrm{C}, 30$ sec at $62{ }^{\circ} \mathrm{C}, 72{ }^{\circ} \mathrm{C}$ for $20 \mathrm{sec}$ and a final extension step of $5 \mathrm{~min}$ at $72{ }^{\circ} \mathrm{C}$. The PCR products were run on $8 \%$ polyacrylamide gel and were visualized by silver staining. Moreover, restriction analyses of C640T and T591A SNPs were performed using Bme1390I and BseNI enzymes (Fermentas, Vilnius, Lithuania), respectively (Table 1). Then the restriction fragments were analyzed on $8 \%$ polyacrylamide gel. Finally, dideoxy termination sequencing with the $\mathrm{ABI}$ automated sequencer was performed for three amplified products of each SNPs to confirm the authenticity of the SNPs genotyping analyses.

\section{Statistical Analyses}

The genotypes and allele frequencies of fimH C640T and T591A SNPs were analyzed, using the $\chi 2$ test. A probability of $\mathrm{P}$ value less than 0.05 was considered 
to be statistically significant. The t-test was also used to analyze the quantitative data. Statistical analyses were performed using SPSS version 19.0 software (SPSS, Inc., Chicago, IL, USA).

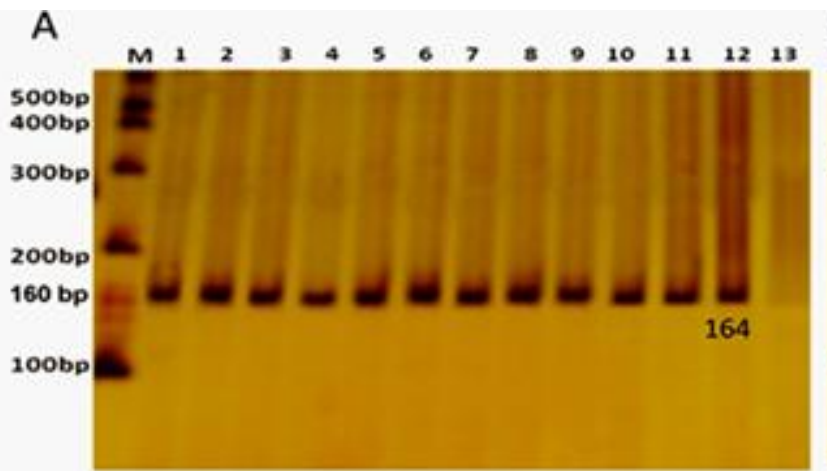

B

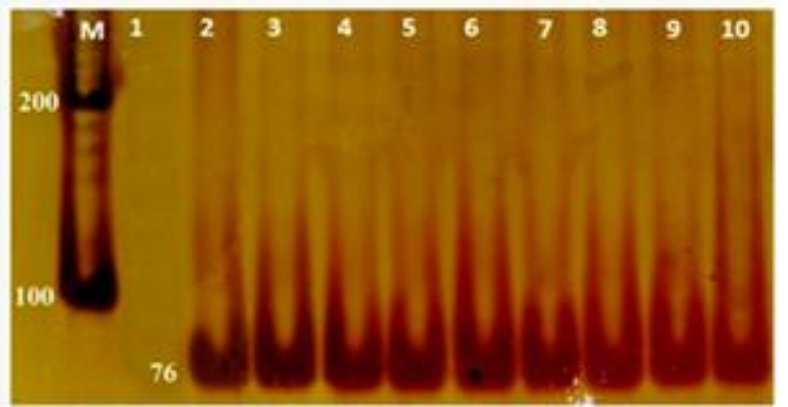

Figure1. Gel Electrophoresis of PCR products containing the C640T and T591A polymorphic sites. Regional amplification of fimH gene, which consist of C640T and T591A polymorphisms results in $164 \mathrm{bp}$ (A) and $76 \mathrm{bp}$ (B) PCR product, respectively. 13 A and 1B: negative controls in two PCR reactions; M: Marker (100 bp); $8 \%$ polyacrylamide gel.

\section{Results}

Forty-five inpatients at the hospital were females and 25 patients were males ( 36 patients younger than 35 years and 35 patients older than 35 years). Forty-two and 28 isolates were recovered from urine samples of female and male outpatients, respectively (32 patients younger than 35 years and 38 patients older than 35

years). The patients aged 1 to 90 years (mean age: 59.5 years). The $\chi 2$ test indicated no significant association between the fimH gene frequency; and gender, age and inpatients or outpatients status (data not shown).

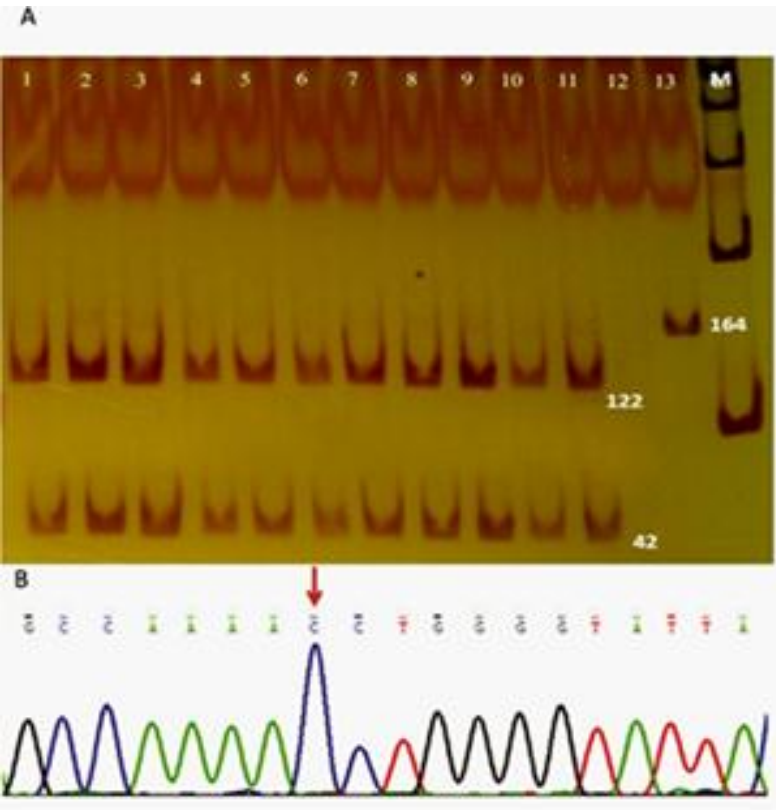

C

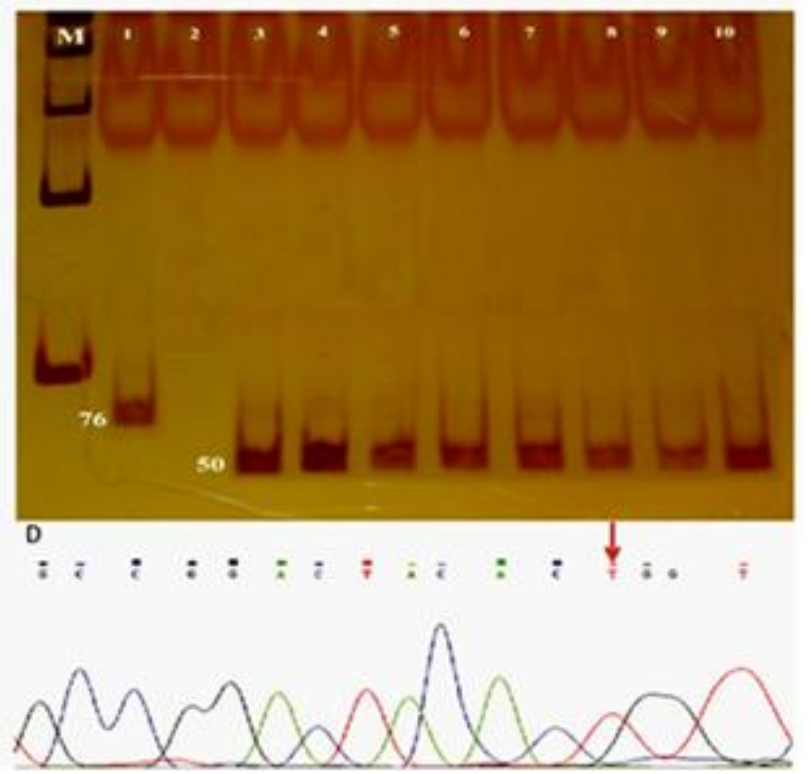

Figure 2. Genotyping analysis of C640T and T591A SNPs. Bme1390I enzyme digested the 164bp fragment PCR product in C location and led to the creation of fragments with 122 and 42 bp lengths (A). T allele of T591A SNP was affected by BseNI restriction enzymes and resulted in creation of 50 and $26 \mathrm{bp}$ fragments. The $26 \mathrm{bp}$ fragment was removed from gel because of the small size of fragment (C). 12A and $2 \mathrm{C}$ : negative control; 13A and 1C: un-digested PCR products; M: Marker (100 bp); $8 \%$ polyacrylamide gel.

Examples of direct DNA sequencing analysis for one sample of C640T (B) and T591A (D) polymorphisms.

\section{Distribution of fimH SNPs}

Regional amplification of fimH gene, which consist of C640T and T591A polymorphic site results in a
$164 \mathrm{bp}$ and a $76 \mathrm{bp}$ PCR products, respectively (Figure. 1). Genotyping was accomplished using the Bme1390I and BseNI restriction enzymes for C640T 
and T591A SNPs, respectively. Bme1390I enzyme only affect the $\mathrm{C}$ allele sequence and it does not have any influence on the $\mathrm{T}$ sequence. This enzyme digested the $164 \mathrm{bp}$ fragment PCR product in C location and led to the creation of fragments with 122 and 42 bp lengths (Figure. 2 A). Relating to T591A $\mathrm{SNP}$, the $\mathrm{T}$ allele was affected by BseNI restriction enzymes and led to the creation of 50 and $26 \mathrm{bp}$ fragments (Figure. 2C). Therefore, discrimination of two alleles was possible and the restricted and nonrestricted fragments were simply recognizable through polyacrylamide gel electrophoresis.

Table 1. PCR-RFLP analyses for detection of C640T and T591A SNPs in fimH gene

\begin{tabular}{|c|c|c|c|c|c|c|c|c|}
\hline \multirow[t]{2}{*}{ Polymorphism } & \multirow{2}{*}{$\begin{array}{l}\text { Restriction } \\
\text { enzyme }\end{array}$} & \multirow{2}{*}{$\begin{array}{l}\text { PCR Product } \\
\text { (bp) }\end{array}$} & \multirow{2}{*}{$\begin{array}{l}\text { RFLP Products } \\
\text { (bp) }\end{array}$} & \multicolumn{5}{|c|}{ The mixture of restriction analyses } \\
\hline & & & & Enzyme & Buffer & $\mathrm{ddH} 2 \mathrm{O}$ & $\begin{array}{l}\text { PCR } \\
\text { Product }\end{array}$ & $\begin{array}{l}\text { Total } \\
\text { volume }\end{array}$ \\
\hline C640T & $\begin{array}{l}(10 \mathrm{U} / \mu \mathrm{l}) \\
\text { Bme1390I }\end{array}$ & 164 & $\begin{array}{l}122,42 * \\
164 * *\end{array}$ & $0.5 \mu \mathrm{l}$ & $1 \mu 1$ & $9 \mu 1$ & $5 \mu 1$ & $15 / 5 \mu 1$ \\
\hline T591A & $\begin{array}{l}(10 \mathrm{U} / \mu \mathrm{l}) \\
\text { BseNI }\end{array}$ & 76 & $\begin{array}{l}50,26 * \\
76^{*}\end{array}$ & $0.5 \mu 1$ & $1 \mu 1$ & $9 \mu 1$ & $5 \mu 1$ & $15.5 \mu 1$ \\
\hline
\end{tabular}

Allelic frequencies of fimH gene C640T and T591A polymorphisms of $130 \mathrm{E}$. coli isolates which contain fimH gene are summarized in Table 3. All E. coli isolates contain the normal allele ( $\mathrm{C}$ and $\mathrm{T}$ allele) of fimH gene C640T and T591A polymorphisms. The comparison of the allelic frequency of C640T and T591A polymorphisms among inpatients and outpatients groups showed similar frequency (Table
2). The association of C640T and T591A polymorphisms and gender status was also analyzed between these two groups (Table 3). Finally, the direct DNA sequencing analyses for three different samples of each SNP approved the presence of normal allele and the results of genotyping analyses (Figure 2B, 2D).

Table 2. Allelic frequency of C640T and T591A SNPs among outpatients and inpatients groups.

\begin{tabular}{lllllll}
\hline & & \multicolumn{2}{c}{ Outpatients } & \multicolumn{2}{c}{ Inpatients } & P \\
\cline { 3 - 6 } Polymorphism & Allelic frequency & $(\%)$ & $\mathrm{n}$ & $(\%)$ & $\mathrm{n}$ & \\
\hline \multirow{2}{*}{ C640T } & $\mathrm{C}$ & 88 & 62 & 97 & 68 \\
& $\mathrm{~T}$ & 0 & 0 & 0 & 0 & 0.05 \\
T591A & $\mathrm{T}$ & 88 & 62 & 97 & 68 & 0 \\
& $\mathrm{~A}$ & 0 & 0 & 0 & & \\
\hline
\end{tabular}

\section{Discussion}

Various SNPs in structural and regulatory genes have remarkable effects on the biology of all organisms (18). Analyses of SNPs in human genome are widely performed to investigate the association between specific SNP and individual susceptibility to various diseases (19). These types of studies lead to identification and discovery of different biomarkers for early diagnosis of the potential individuals (20). In recent years, many SNPs have been discovered in different regulatory and structural genes of bacterial pathogens. Scientists have focused on the association between different SNPs of bacterial pathogens and its effect on the severity of pathogenicity of pathogens to cause disease $(4,21)$. UTI is a major health problem and one of the most frequent hospital acquired infections, with $E$. coli as a predominant pathogen in most cases. Genetic variations in human such as different polymorphisms in Toll-like receptors (TLR) family underlie the susceptibility for UTI. E. coli virulence genes are also main factors in the etiology of UTIs, as well as human susceptibility factors $(1,22,23)$. It has been reported that the UPEC strains which cause most UTIs form a genetically different group with multiple virulence factors (24). Generally, the combination of various factors in host and pathogen has determined the individual susceptibility to UTIs. 
Among all diverse range of UPEC's virulence factors, type 1 fimberia encoding genes are mostly investigated. Type 1 fimberia contains an adhesion at their tip, which is encoded by fimH gene as a significant factor in host-pathogen interactions. Scientists particularly targeted the FimH adhesion to prevent from its interaction with host cells using soluble receptors. These investigations suggested FimH receptors as potentially important vaccine candidates $(25,26)$. Moreover, The FimH phenotypic variants are mainly the result of SNPs in fimH gene (27). The naturally occurring of these variants was investigated through different studies. These studies reported that the naturally occurring fimH variations significantly alter the tissue tropism of E.coli. Furthermore, the selection of genetic variations in the FimH gene as well as acquisition of virulence genes, results in the shifting from commensal to virulent phenotype $(28,29)$. Various fimH SNPs were analyzed and reported for $E$. coli clinical isolates by Dias et al. Some fimH polymorphisms such as C640T and T591A SNPs were found only among hospital or community isolates (30). In this study, we investigated the association between C640T and T591A SNPs of fimH gene and the ability of UPEC to cause UTIs.

In agreement with other studies, we previously reported a high frequency of fimH gene $(92.8 \%)$ among $140 \mathrm{E}$. coli isolates (31). The incidence of fimH gene in E. coli strains isolated from Romanian adult with UTI was $86 \%$ (32). In addition, Andreu et al. identified the incidence of fimH gene in E. coli strains isolated from patients with UTI as $90 \%$ (33). In another study, Joachim et al. reported that the frequency rate of fimH was 95\% among UPEC strains. In further studies by Tarchouna et al. and Daniela et al. which were performed on virulence genes in $E$. coli isolated from patients with UTIs, the prevalence of fimH gene was $68 \%$ and $86.1 \%$, respectively $(28,32)$. The high frequency of fimH gene in all studies relating to UTIs indicates the critical roles of this virulence factor in $E$. coli pathogenesis. In the present study, among all E. coli isolates which contained fimH gene (130 samples), the frequency of $\mathrm{C}$ allele in the C640T polymorphic site is $97 \%$ and $88 \%$ in outpatients and inpatients groups, respectively. In fact, there is no allelic transition in this position and the frequency of the $\mathrm{T}$ allele was $0 \%$. Absolutely same results were observed relating to the allelic frequency of the $\mathrm{T}$ allele in T591A site. The frequency of the A allele was $0 \%$ and no allelic shifting was observed relating to T591A SNP. Our results are in agreement with those of Abdallah et al. in these polymorphic sites (34). Furthermore, the absence of the $\mathrm{T}$ and $\mathrm{A}$ allele in these positions among the outpatients group is not similar to the results of Dias et al. The differences observed in this study and reports from Dias et al. (29) could be explained by geographic location and the type, source and size of samples. In conclusion, our study indicated that: 1) FimH is one of the most significant virulence factors among UPECs; 2) further studies are required to determine the association between different SNPs of fimH gene of isolated UPECs from UTIs patients and the ability of UPECs to cause UTIs.

\section{Acknowledgements}

This study was performed at Cell and Molecular Research Center in Shahrekord University of Medical Sciences and was financially supported by the Graduate Office, Shahrekord University of Medical Sciences.

\section{Conflict of interest}

The authors declare no conflict of interest.

\section{Author Contributions}

MR, HZ and GhA have made substantial contributions to the conception and design of the study and interpretation of data. MR performed the experiments. Drafting the article or revising it critically for important intellectual content have done by GhA and DF. All authors also contributed in final approval of the version of manuscript which to be submitted.

\section{Support/Funding}

This work was supported by the Graduate Office, and grant No. 1113 provided by Shahrekord University of Medical Sciences.

\section{References}

1. Minardi D, d'Anzeo G, Cantoro D, Conti A, Muzzonigro G. Urinary tract infections in women: etiology and treatment options. Int J Gen Med. 2011; 4:333. PMID: 21674026

2. Ronald A. The etiology of urinary tract infection: traditional and emerging pathogens. Dis Mon. 2003; 49(2):71-82. PMID: 12601338

3. Dadashi M, Eslami G, Goudarzi H, Fallah F, Hashemi A, Dabiri H, Taheri S, Ardeshiri N. Antibacterial Effects of Citrus aurantium on Bacteria Isolated from Urinary Tract Infection. Res Mol Med. 2015; 15:3(4):47-50.

4. Barber AE, Norton JP, Spivak AM, Mulvey MA. Urinary tract infections: current and emerging management strategies. Clin Infect Dis. 2013; 57(5):719-24. PMID: 23645845

5. Bien J, Sokolova O, Bozko P. Role of uropathogenic Escherichia coli virulence factors in development of urinary tract infection and kidney damage. Int J Nephrol. 2012; 681473. PMID: 22506110

6. Hooton TM, Stamm WE. Diagnosis and treatment of uncomplicated urinary tract infection. Infect Dis Clin North Am. 


\section{7; 11(3):551-81. PMID: 9378923}

7. Mulvey MA. Adhesion and entry of uropathogenic Escherichia coli. Cell Microbiol. 2002; 4(5):257-71. PMID: 12027955

8. Asadi S, Kargar M, Solhjoo K, Najafi A, Ghorbani-Dalini S. The Association of Virulence Determinants of Uropathogenic Escherichia coli With Antibiotic Resistance. Jundishapur J Microbiol. 2014; 7(5). PMID: 25147722

9. Kudinha T, Kong F, Johnson JR, Andrew SD, Anderson P, Gilbert GL. Multiplex PCR-based reverse line blot assay for simultaneous detection of 22 virulence genes in uropathogenic Escherichia coli. Appl Environ Microbiol. 2012; 78(4):1198-202. PMID: 22156422

10. Dielubanza EJ, Schaeffer AJ. Urinary tract infections in women. Med Clin North Am. 2011; 95(1):27-41. PMID: 21095409

11. Klemm P, Christiansen G. Three fim genes required for the regulation of length and mediation of adhesion of Escherichia coli type 1 fimbriae. Mol Gen Genet. 1987; 208(3):439-45. PMID: 2890081

12. Choudhury D, Thompson A, Stojanoff V, Langermann S, Pinkner J, Hultgren SJ, et al. X-ray structure of the FimC-FimH chaperone-adhesin complex from uropathogenic Escherichia coli. Science. 1999; 285(5430):1061-6. PMID: 10446051

13. Sokurenko EV, Feldgarden M, Trintchina E, Weissman SJ, Avagyan S, Chattopadhyay S, et al. Selection footprint in the FimH adhesin shows pathoadaptive niche differentiation in Escherichia coli. Mol Biol Evol. 2004; 21(7):1373-83. PMID: 15044596

14. Hommais F, Gouriou S, Amorin C, Bui H, Rahimy MC, Picard $\mathrm{B}$, et al. The FimH A27V mutation is pathoadaptive for urovirulence in Escherichia coli B2 phylogenetic group isolates. Infect Immun. 2003; 71(6):3619-22.PMID: 12761149

15. Weissman SJ, Moseley SL, Dykhuizen DE, Sokurenko EV. Enterobacterial adhesins and the case for studying SNPs in bacteria. Trends Microbiol. 2003; 11(3):115-7. PMID: 12648942.

16. Garcia LS. Clinical microbiology procedures handbook, Volumes 1, 2 and 3: ASM press; 2010.

17. Nason FL. Specimen collection and test unit. Google Patents; 1987.

18. Morin PA, Luikart G, Wayne RK. SNPs in ecology, evolution and conservation. Trends Ecol Evol. 2004; 19(4):208-16.

19. Altshuler D, Daly MJ, Lander ES. Genetic mapping in human disease. science. 2008; 322(5903):881-8. PMID: 18988837

20. Taylor JG, Choi E-H, Foster CB, Chanock SJ. Using genetic variation to study human disease. Trends Mol Med. 2001; 7(11):507-12. PMID: 11689336

21. Schembri MA, Sokurenko EV, Klemm P. Functional flexibility of the FimH adhesin: insights from a random mutant library. Infect Immun. 2000; 68(5):2638-46. PMID: 10768955

22. Hawn TR, Scholes D, Wang H, Li SS, Stapleton AE, Janer M, et al. Genetic variation of the human urinary tract innate immune response and asymptomatic bacteriuria in women. PLoS One. 2009; 4(12):e8300. PMID: 20016852
23. Hawn TR, Scholes D, Li SS, Wang H, Yang Y, Roberts PL, et al. Toll-like receptor polymorphisms and susceptibility to urinary tract infections in adult women. PloS one. 2009; 4(6):e5990. PMID: 19543401

24. Abdi HA, Rashki A. Comparison of Virulence Factors Distribution in Uropathogenic E. coli Isolates From Phylogenetic Groups B2 and D. Int J Enteric Pathog. 2014; 2(4):e21725.

25. Hoepelman I, Meiland R, Langermann S. Candidate vaccine against urinary tract infections. Ned Tijdschr Geneeskd. 2001; 145(38):1860-2.

26. Langermann S, Palaszynski S, Barnhart M, Auguste G, Pinkner $\mathrm{JS}$, Burlein $\mathrm{J}$, et al. Prevention of mucosal Escherichia coli infection by FimH-adhesin-based systemic vaccination. Science. 1997; 276(5312):607-11. PMID: 9110982

27. Tartof SY, Solberg OD, Riley LW. Genotypic analyses of uropathogenic Escherichia coli based on fimH single nucleotide polymorphisms (SNPs). J Med Microbiol. 2007; 56(10):1363-9. PMID: 17893175

28. Tarchouna M, Ferjani A, Ben-Selma W, Boukadida J. Distribution of uropathogenic virulence genes in Escherichia coli isolated from patients with urinary tract infection. Int J Infect Dis. 2013;17(6):e450-e3. PMID: 23510539

29. Sokurenko EV, Chesnokova V, Dykhuizen DE, Ofek I, Wu XR, Krogfelt KA, et al. Pathogenic adaptation of Escherichia coli by natural variation of the FimH adhesin. Proc Natl Acad Sci. 1998; 95(15):8922-6. PMID: 9671780

30. Dias RC, Moreira BM, Riley LW. Use of fimH singlenucleotide polymorphisms for strain typing of clinical isolates of Escherichia coli for epidemiologic investigation. J Clin Microbiol. 2010; 48(2):483-8. PMID: 20018817

31. Hojati Z, Zamanzad B, Hashemzadeh M, Molaie R, Gholipour A. Detection of FimH Gene in Uropathogenic Escherichia coli Strains Isolated From Patients With Urinary Tract Infection. Jundishapur J Microbiol. 2015; 8(2): e17520. PMID: 25825648

32. Usein CR, Damian M, Tatu-Chitoiu D, Capusa C, Fagaras R, Tudorache D, et al. Prevalence of virulence genes in Escherichia coli strains isolated from Romanian adult urinary tract infection cases. J Cell Mol Med. 2001; 5(3):303-10. PMID: 12067489

33. Andreu A, Xercavins M, Fernandez F. Type 1 fimbriae, $P$ fimbriae and $\mathrm{X}$ adhesins in Escherichia strains causing pyelonephritis, cystitis and recurrent urinary infections. Medicina clinica. 1989; 92(11):409-12. PMID: 2566727

34. Abdallah KS, Cao Y, Wei D-J. Epidemiologic Investigation of Extra-intestinal pathogenic E. coli (ExPEC) based on PCR phylogenetic group and fimH single nucleotide polymorphisms (SNPs) in China. Int J Mol Epidemiol Genet. 2011; 2(4):339. PMID: 22199997 